
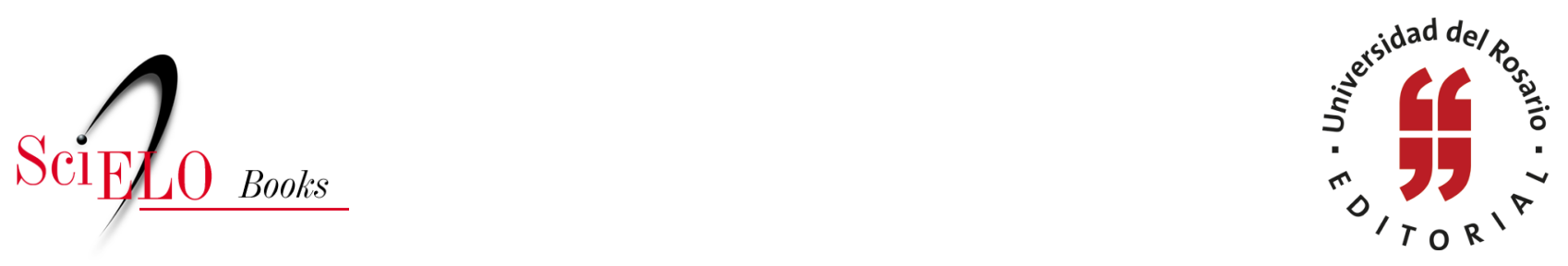

\title{
1. De cómo un tío mío atracó a una tía mía
}

\author{
César Augusto Tapias Hernández
}

TAPIAS HERNÁNDEZ, C.A. De cómo un tío mío atracó a una tía mía. In: Historias de familia: Etnografía delirante sobre el amor, la violencia y las drogas [online]. Bogotá: Editorial Universidad del Rosario, 2014, pp. 5-8. Textos de ciencias humanas collection. ISBN: 978-958-738-543-4. https://doi.org/10.7476/9789587385434.0002.

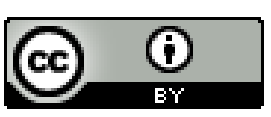

All the contents of this work, except where otherwise noted, is licensed under a Creative Commons Attribution 4.0 International license.

Todo o conteúdo deste trabalho, exceto quando houver ressalva, é publicado sob a licença Creative Commons Atribição 4.0.

Todo el contenido de esta obra, excepto donde se indique lo contrario, está bajo licencia de la licencia Creative Commons Reconocimento 4.0. 


\title{
1. De cómo un tío mío atracó a una tía mía
}

\author{
"Póngale ánimo a la cosa". Él mira displicente y replica: "es que \\ la cuestión no es de ánimo". Y suena una guitarra eléctrica: \\ "Dinero... Angustias... Problemas... Dinero... Sistemaaa". \\ Víctor Gaviria, Rodrigo D no futuro
}

La tía Irene les llevaba almuerzo a unas compañeras del trabajo. Eso fue un lunes después de día de madres. Había quedado de un sudado de gallina que se hizo en la casa, entonces había empacado un poco para las muchachas.

-Entonces ¿lo que te robaron fue el almuerzo, pues?

${ }_{-¿ E l}$ almuerzo? Y un cheque de 60.000 pesos de un préstamo para hacer unos arreglos a la casa.

— ¿60.000 pesos que eran lo que hoy más o menos cuánto?

- Por ahí unos 200.000 pesos.

-Humm, mero gol el de mí tío $\mathrm{H}$, ¿no, tía Irene?

-Quien sabe, porque no lo cobraron...

De la Cooperativa dieron una orden de no pagarlo; además informaron el número de la cédula que también estaba en el bolso. De todas formas, había que esperar tres o cuatro meses para ver sí lo cobraban, no lo hicieron. Luego me dieron otro cheque.

-Y ¿ cómo fue la vuelta, pues?

-Eran tres muchachos. A esa hora, 4:30 a. m. Fijo eran ladrones.

En esa época, años ochenta, muchacho por ahí parao en una esquina tenía que ser ladrón.

Veo que se vienen, y yo echo a correr. Yo bajaba por aquí (señala mi tía la calle); pero cogía pa' la otra calle, la de allá: a salir justo al paradero de buses de Castilla 263. Me agarraron, y uno de ellos me apercuelló y me puso la rodilla en 
la espalda. Arturo, mi marido, siempre me ponía cuidado y apenas los vio encima de mí, les gritó:

—iSuéltenla, pues, güevones!

-Yo no me acuerdo si había matorrales por aquí, o si esto era peladero. Uno de ellos dijo: “se vino ese negro gonorrea, jálale, jálale ese bolso...”. Me lo jalaron y salieron corriendo por ahí pa’ bajo. Arturo era con la cantaleta: "con ese bolso tan grande, la van a atracar, la van a atracar, la van a atracar...” ¡ Y f fijo me atracaron! Un bolso grande llamaba mucho la atención. De por sí a esa horas había poquito carro abajo, no existía otra ruta de buses y por aquí bajaba gente hasta del Picacho.

$-i A$ robar?

-No. A coger bus.

-Entonces la fila que había en el paradero era inmensa y en la carrera, los ladrones la partieron justo donde había un policía.

-Y el policía, ¿qué hizo?

— ¡Nada! Yo no puedo hacer nada señora, porque no estoy de servicio, fue lo que dijo.

Se salvó mi tío H con la suya, pienso, y recuerdo que en estos días un primo lo vio en televisión mientras informaban del hacinamiento en las estaciones de policía de Bogotá, y en una de tantas celdas agolpadas de presos estaba encanado H Tales.

-Yo conocía a todos los hermanos de su papá. Y a lo mejor él haya dicho algo en la casa de sus abuelos, porque los papeles míos aparecieron por ahí cerquita.

-En esas épocas, ¿de dónde salían los ladrones?

-De todas partes. No ve, pues, a su tío que venía de por donde su abuela.

-César, y ¿usted ha visto que a uno lo atraquen y le devuelvan la plata?, dice la prima Lucía.

—... Espere, espere ahora me cuenta esa historia ¿sí? Tía Irene, y ¿más o menos cuándo fue eso?

- ¿Qué es la preguntadera suya?, ¿va a ser una tesis con eso o qué?

— ¿Qué año era eso?, no más dígame eso...

—Como al año y medio de yo estar trabajando en Tejidos Wagner... 1981.

-Y usted, ¿se acuerda de cómo iba vestida ese día?

—Ehhhh, pero vean a este... Quizás de zapatos altos y un vestido de prenses...

-Oíste, amá —interrumpe de nuevo Lucía_- ese César va a escribir una historia con eso, póngale cuidado...

Mi tía Irene sonríe y llama a Arturo, su esposo: “Arturo vaya saque 500 pesos de la monederita y compre unos plátanos verdes". 
Este primer relato surgió en la sala de mi tía Irene acompañados de los boleros entre noticias de la Radio Paisa: final de día en una sala acogedorcita. Estuvieron mi tía Irene, su esposo y primo Arturo, Lucía una de las muchachas y Sandra, la primera nieta de mi tía. La gran ausente: la televisión.

Estas historias de mi familia son como postales de diferentes lugares que, encadenadas para su lectura, dejan ver el viaje que hice mientras observaba y escuchaba historias de tíos y tías, de abuelos y abuelas, justo después de terminar la universidad. Fue un viaje por el recuerdo, por la memoria, por el amor, por el dolor, por los excesos... por todo aquello que me constituía como miembro de mi familia. Viajaba reflejándome en esas historias. Imaginando mi futuro tras esas historias. Fue un viaje alucinante y alucinógeno....Y no está mal ver como un viaje relatado las historias que a continuación encontrará; eso es la etnografía, un viaje y su relato. Sobre lo que se vivió. En torno a lo que se escribió. Las imágenes e historias que obtuve están transcritas en este libro, donde se relata un viaje de 36 escalas o relatos, cada uno de una extensión de no más de tres cuartillas, atravesadas por una reflexión sociológica en torno al lugar que ocupamos no solo dentro de la familia, sino como grupo en la sociedad. De joven sociólogo, quería entender cómo me construía la familia, y el lugar que ocupábamos en la sociedad que iba como en el lomo de un caballo desbocado entre los siglos XX y XXI.

El ejercicio de reunir estas historias, este stock de conocimientos disponibles, se propuso para encontrar las palabras y los signos que como prenociones sobre la vida cotidiana de un grupo individuos ilustraran (no solo) un mar de problemas (sociológicos): anomías, malestares, por ejemplo, de los delirios de violencia, el abuso de alcohol y drogas, las rencillas familiares, etc., sino también solidaridades, y sobre todo amores: múltiples y coloridas representaciones que los individuospartes del grupo (mis familiares y yo mismo) hacemos de nuestro estado, de nuestras condiciones, del lugar que ocupamos con respecto a los demás. Pero, ¿qué trabajo conceptual o sobre qué líneas teóricas se desarrolló este viaje etnográfico? Más aún... metodológicamente, ¿cómo estudia un sociólogo a su propia familia? El lector se topará con interesantes referentes bibliográficos de espectros sociológicos, filosóficos, antropológicos y poéticos a propósito de la ebriedad, del poder, de la desigualdad de género y otras violencias, junto a la descripción etnográfica de los rasgos culturales de un grupo humano trasladado con los años desde el campo 
a la gran ciudad y unas claves metodológicas para comprender cómo es que se documentó tal hazaña.

Como profesional de las ciencias sociales suelto en las calles, me agarré de lo primero que entendí de mis lecturas en el metro, el llamado del sociólogo francés Pierre Bourdieu (2000), y lo que me correspondía hacer como científico social: demandar al razonamiento, a la revelación de las causas estructurales que las palabras y los signos aparentes no develaban. Intento con este texto, especialmente tras su lectura, hacer visibles los mecanismos que hacen que funcione el mundo social que construimos en nuestras familias, es decir, la estructura de la interacción que configuramos: mi familia en su forma de ser, un fenómeno social total de donde se derivan procesos como la comunicación y la expresión de sentimientos. Y me propongo este análisis, no para neutralizar los detonantes o causas de las formas anómalas que determinan nuestra interacción, ni para resolver los problemas que generan lo que somos. Basta con comprender las verdaderas causas del malestar que solo se expresan a la luz de la cotidianidad. Y de eso hay de sobra en este libro, una cotidianidad explorada y descrita bajo el paradigma cualitativo, utilizando la etnografía como metodología bajo la guía de tres claves posmodernas: 1) a la manera de los cronotopos de Lévi-Strauss (1997) en Tristes trópicos, las historias como configuraciones espaciotemporales construidas en escenarios ficcionales donde tienen lugar ciertos acontecimientos; 2) de la noción bajtiniana de carnaval (1953), en la que desaparece la diferencia entre sujeto y objeto, como resultado de la concepción dialógica del lenguaje, esta etnografía es una gran conversación, y 3) de la problematización de la autoridad y la escritura etnográficas mediante el uso del collage o montaje literario, intentando encarnar la vanguardia posmoderna entre Leiris (1934) y Taussig (2002), yendo de la actividad literaria a la práctica etnográfica que describe el viaje que he visto, y a mí mismo como soy. 